\title{
Educational needs assessment for men's participation in perinatal care
}

\author{
M. Simbar, ${ }^{1}$ F. Nahidi, F. Ramezani-Tehrani ${ }^{2}$ and A. Akbarzadeh ${ }^{3}$
}

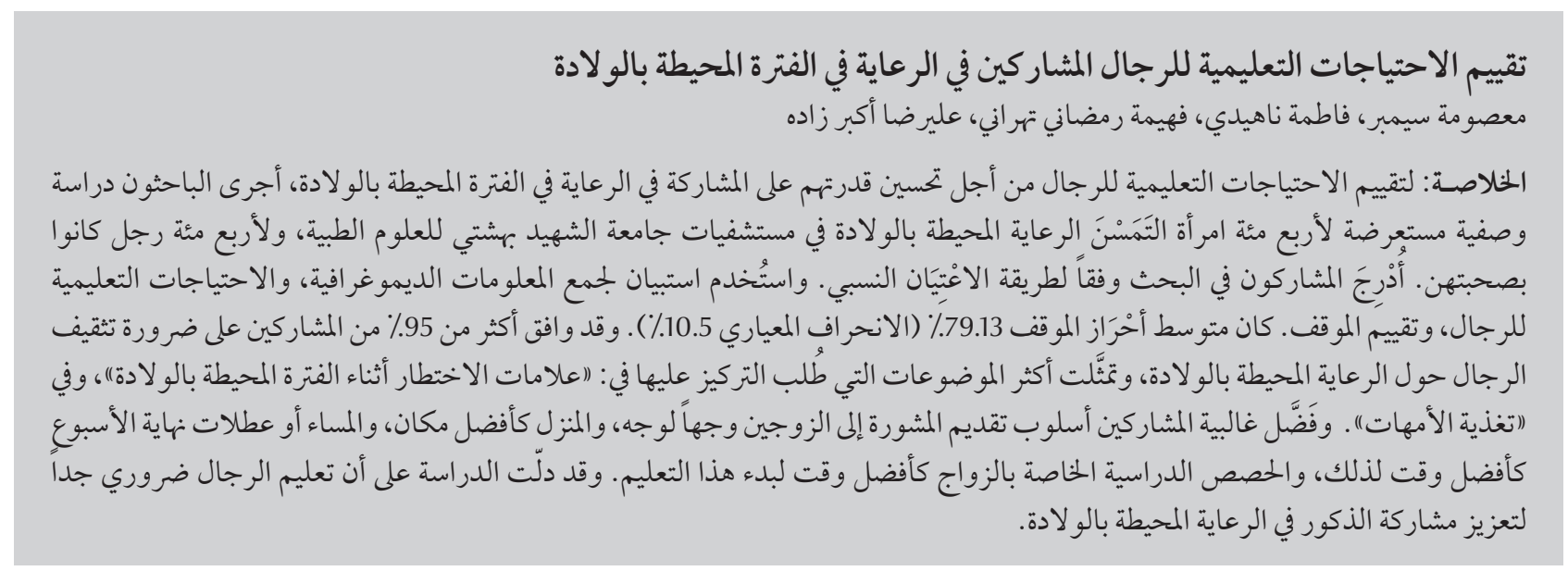

ABSTRACT To assess men's educational needs to improve their involvement in perinatal care we carried out a descriptive, cross-sectional study on 400 women seeking perinatal care in Shahid Beheshti University of Medical Sciences hospitals and 400 men who were accompanying them. Participants were recruited using a quota sampling method. A questionnaire was used to collect information on demography, men's educational needs and attitude assessment. The mean attitude score was 79.13\% (SD 10.5\%). More than 95\% of participants agreed with perinatal care education for men and the content most required was "Signs of risks during the perinatal period" and "Mothers' nutrition". The majority of participants preferred the face-to-face couples' counselling method, at home as the best place, evening and weekends as the best time and marriage classes as the best time for initiation. Men's education is necessary to promote male involvement in perinatal care.

\section{Évaluation des besoins en formation des hommes pour leur participation aux soins périnatals}

RÉSUMÉ En vue d'améliorer l'implication des hommes dans les soins périnatals, nous avons conduit une étude descriptive et transversale portant sur 400 femmes consultant pour des soins périnatals dans les hôpitaux de I'Université des sciences médicales Shaheed Beheshti (République islamique d'Iran), et sur les besoins en formation des 400 hommes les accompagnant. Les participants ont été recrutés à l'aide d'une méthode de sondage par quotas. Un questionnaire a été utilisé pour collecter les données démographiques ainsi que les besoins en formation des hommes et évaluer leur attitude. Le score moyen concernant les attitudes était de 79,13\% (E.T. 10,5\%). Plus de 95 \% des participants approuvaient l'idée d'une formation en soins périnatals destinée aux hommes. "Les signes de risque pendant la période périnatale » et « la nutrition maternelle » étaient les thèmes les plus demandés. La majorité des participants préférait recevoir des conseils en rendez-vous de couple, à domicile, en soirée et pendant les weekends. Les cours sur le mariage étaient considérés comme le meilleur moment pour débuter. Les hommes doivent recevoir une formation pour les encourager à s'impliquer dans les soins périnatals.

${ }^{7}$ Department of Reproductive Health; ${ }^{2}$ Reproductive Endocrinology Research Centre; ${ }^{3}$ Department of Biostatistics, Shahid Beheshti University of Medical Sciences, Tehran, Islamic Republic of Iran (Correspondence to M. Simbar: msimbar@sbmu.ac.ir,msimbar@yahoo.com;masoumeh. simbar@gmail.com).

Received: 15/09/09; accepted: 25/01/10 


\section{Introduction}

Acceleration in decreasing of maternal mortality has been announced as the top priority of reproductive health programmes by the World Health Organization [1]. Nowadays, men's participation in maternal health care is considered a strategy for decreasing maternal mortality, however, men are not seen in maternal services and do not have access to the information necessary for making informed decisions about protection and improvement of maternal health [2]. Men can participate in maternal health by being involved in safe motherhood programmes. They can actively participate in: contraceptive use, child limitation and spacing, ensuring childbirth is attended by skilled health personnel, neonatal care during the postpartum period, playing a responsible role in the family and eliminating violence against women [3]. The Population Council reported successful male involvement in prenatal care in the programme on men's role in India and South Africa [4].

There are gaps in our knowledge about the role of the father in the family, especiallyin theperinatal period. Expectant fathers can play roles such as coach, witness or assistant in perinatal care and are able to learn participation through education [5]. In addition, fathers need to adapt to their new role as parents, and it is sometimes more difficult for them because they are usually ignored by the family and by health personnel [6]. Education to promote men's participation has positive effects on maternal and neonatal care as evidenced in different countries. In Indonesia education improved men's knowledge and prepared them to help in the process of childbirth [7]. In Turkey, education about the role of family members in perinatal care led to improvement in the participants' knowledge, attitudes and practices regarding reproductive health, mainly in the area of family planning, neonatal health, breastfeeding and supporting their wives. The authors recommended culturally appropriate prenatal education free of charge for groups of men $[8,9]$. Men's education in India was mentioned as a contributor in the success of a maternal health programme [10]. In El Salvador, men's participation in a prenatal care programme was considered a new opportunity for men to be involved in their own and their family's health improvement [11]. An Egyptian study showed that family planning counselling with couples during the antenatal period had a positive effect on couples' knowledge and practice [12]. Men's participation in breastfeeding programmes increased the rate and continuity of breastfeeding [13] Men's education had positive effects on spousal communication and their parental roles [14]. There have been a few studies in Iran to assess male participation in family planning programmes [15-17] but their participation in perinatal care programmes has been less studied even though male participation has recently been emphasized to achieve Millennium Development Goals such as improving maternal health, gender equity, decreasing child mortality, eliminating illiteracy and eradicating diseases as well as the objectives of the International Conference on Population and Development [18-20]. Therefore, men require educational programmes for their participation.

This study aims to assess educational needs for men's participation in perinatal care as a base for an effective, culturally appropriate, acceptable and feasible education.

\section{Methods}

This was a cross-sectional study and the quantitative part of a sequential qualitative-quantitative triangulation research strategy to assess men's educational needs for participation in prenatal care.

The qualitative part of the study was performed using focus group discussions (FGD) [21]. Eight groups of clients of SBMU perinatal services (including 4 groups of women and 4 groups of men) participated in FGDs. A semi-structured questionnaire with 7 guide questions was used. The aim of FGDs was exploration of hidden opinions of the community and to design an appropriate questionnaire for this study (quantitative part).

Using a non-randomized quota sampling method, 800 subjects (including 400 male and 400 female subjects) participated in the study from May 2008 to January 2009. The sample size was calculated using the formula for descriptive studies [22]. The participants were clients of perinatal services (prenatal care services and postpartum wards) of Mahieh, Taleghani, Shohada and Emam-Hosein hospitals of Shahid Beheshti University of Medical Sciences. Women were interviewed in the prenatal care clinic or postpartum care units and men were interviewed in the waiting rooms after a detailed explanation about the aims and procedure of the study and taking a written consent for their participation.

The tool for data collection was a structured questionnaire, which was developed after content analysis and extraction of the statements from the results of the qualitative part of the study [21]. The questionnaires were completed by interview and there were no drop-outs among the participants of the study, nor were the data incomplete in any of the questionnaires. All interviews were performed by a trained midwife. She carried out the interviews on working days and continued until completing of sampling process. There were only 5 cases of refusal for participation.

The questionnaire included $3 \mathrm{sec}-$ tions: demographic (12 questions), educational needs assessment (22 questions), and a Likert scale to assess attitude towards male participation (30 statements). Each questionnaire required 45 minutes to be completed. 
The content and face validity of the questionnaire were assessed by 10 reproductive health experts. The reliability of the questionnaire was assessed using test retest and half splitting methods and was confirmed by 0.92 and 0.96 correlation coefficient, respectively. To assess test retest reliability, 15 questionnaires were filled up by 20 male and female participants twice with a 1-week interval. Cronbach alpha coefficient of 0.87 confirmed the reliability of the questionnaire.

The aims and the procedure of the study were explained to the participants, and their written consent was given before the interviews. Approval of the ethical committee of Shahid Beheshti University of Medical Sciences was obtained for the study.

To calculate attitude score, each statement scored 0, 1 or 2 (disagree, neutral and agree), respectively. Then the sum of the scores was calculated as a percentage. Scores 0\%-33\%, 34\%-66\% and $67 \%-100 \%$ were classified as negative, neutral and positive attitude respectively.

The data were analysed using SPSS, version 16 , using the $t$-test, analysis of variance (ANOVA) and chi squared tests with $95 \%$ confidence interval.

\section{Results}

Demographic characteristics of the participants are presented in Table 1 . The mean age of the 800 participants was 28.32 [standard deviation (SD) 5.51; 95\% CI: 17-42] years.

The mean attitude score of the participants was 79.13 (SD 10.52. The $t$-test demonstrated men had a significantly higher attitude score, 82.4 (SD

\begin{tabular}{|c|c|c|c|c|c|c|}
\hline \multirow[t]{2}{*}{ Characteristic } & \multicolumn{2}{|c|}{$\begin{array}{l}\text { Females } \\
(n=400)\end{array}$} & \multicolumn{2}{|c|}{$\begin{array}{c}\text { Males } \\
(n=400)\end{array}$} & \multicolumn{2}{|c|}{$\begin{array}{c}\text { Total } \\
(\boldsymbol{n}=\mathbf{8 0 0})\end{array}$} \\
\hline & \multicolumn{2}{|c|}{ Mean (SD) } & \multicolumn{2}{|c|}{ Mean (SD) } & \multicolumn{2}{|c|}{ Mean (SD) } \\
\hline Age & \multicolumn{2}{|c|}{$26.79(5.23)$} & \multicolumn{2}{|c|}{$29.86(4.45)$} & \multicolumn{2}{|c|}{$28.32(5.51)$} \\
\hline No. of children & \multicolumn{2}{|c|}{$1.12(0.99)$} & \multicolumn{2}{|c|}{$1.07(0.67)$} & \multicolumn{2}{|c|}{$1.09(0.88)$} \\
\hline \multirow[t]{2}{*}{ Size offamily } & \multicolumn{2}{|c|}{$3.42(1.54)$} & \multicolumn{2}{|c|}{$3.21(0.76)$} & \multicolumn{2}{|c|}{$3.31(1.22)$} \\
\hline & No & $\%$ & No & $\%$ & No & $\%$ \\
\hline \multicolumn{7}{|l|}{ Education } \\
\hline Illiterate & 28 & 7.0 & 28 & 7.0 & 56 & 7.0 \\
\hline Primary school & 67 & 16.5 & 100 & 25.0 & 167 & 20.9 \\
\hline Middle school & 52 & 13.0 & 66 & 16.5 & 118 & 14.8 \\
\hline High school & 220 & 55.0 & 162 & 40.5 & 382 & 47.8 \\
\hline University & 33 & 8.5 & 44 & 11.0 & 77 & 9.6 \\
\hline \multicolumn{7}{|l|}{ Employment } \\
\hline Unemployed/householder & 384 & 96.0 & 0 & 0.0 & 384 & 48.0 \\
\hline Labourer & 7 & 1.5 & 120 & 30.0 & 127 & 15.9 \\
\hline Office personnel & 4 & 1.0 & 120 & 30.0 & 124 & 15.5 \\
\hline Teacher & 4 & 1.0 & 0 & 0.0 & 4 & 0.5 \\
\hline Small business & 1 & 0.5 & 160 & 40.0 & 161 & 20.1 \\
\hline \multicolumn{7}{|l|}{ Accommodation } \\
\hline Rented & 241 & 60.5 & 292 & 73.0 & 533 & 66.6 \\
\hline Owned & 110 & 27.5 & 68 & 17.0 & 178 & 22.3 \\
\hline Living in family home & 49 & 12.2 & 40 & 10.0 & 89 & 11.1 \\
\hline \multicolumn{7}{|l|}{ Monthly income (US\$) } \\
\hline 0 & 4 & 0.5 & 0 & 0.0 & 4 & 0.5 \\
\hline$<150$ & 387 & 96.8 & 2 & 0.5 & 389 & 48.6 \\
\hline 150 to $<300$ & 3 & 0.5 & 152 & 38.0 & 155 & 19.4 \\
\hline 300 to $<500$ & 6 & 1.5 & 234 & 58.5 & 240 & 30.0 \\
\hline 500 to $<1000$ & 0 & 0.0 & 8 & 2.0 & 8 & 1.0 \\
\hline$>1000$ & 0 & 0.0 & 4 & 1.0 & 4 & 0.5 \\
\hline
\end{tabular}

$S D=$ standard deviation. 


\begin{tabular}{|c|c|c|c|c|c|c|}
\hline \multirow[t]{2}{*}{ Statement } & \multicolumn{2}{|c|}{ Agree } & \multicolumn{2}{|c|}{ Neutral } & \multicolumn{2}{|c|}{ Disagree } \\
\hline & No. & $\%$ & No. & $\%$ & No. & $\%$ \\
\hline Education on prenatal care is necessary for both, fathers and mothers & 793 & 99.1 & 1 & 0.1 & 6 & 0.8 \\
\hline Pregnant mothers need a lot of emotional support during pregnancy & 791 & 98.9 & 1 & 0.1 & 8 & 1.0 \\
\hline The media can promote male participation in maternal health & 781 & 97.6 & 5 & 0.6 & 14 & 1.8 \\
\hline He(I) provide(s) my(her) favourite food as soon as possible & 779 & 97.4 & 3 & 0.4 & 18 & 2.2 \\
\hline Fathers should have perinatal leave for participation in the birth & 775 & 96.9 & 3 & 0.4 & 22 & 2.8 \\
\hline Fathers should be allowed to attend prenatal visits & 771 & 96.4 & 7 & 0.9 & 22 & 2.8 \\
\hline Fathers would participate if they had perinatal leave & 763 & 95.4 & 5 & 0.6 & 32 & 4.0 \\
\hline He(I) help(s) because the child belongs to us both & 760 & 95.1 & 3 & 0.4 & 36 & 4.5 \\
\hline He(I) care(s) about my (her) nutrition during pregnancy & 749 & 93.6 & 5 & 0.6 & 46 & 5.8 \\
\hline Movies and TV serials may contribute in promotion of men's participation & 724 & 90.5 & 5 & 0.6 & 71 & 8.9 \\
\hline $\mathrm{He}(\mathrm{I})$ care(s) about the signs of risks during the pregnancy & 709 & 88.6 & 1 & 0.1 & 90 & 11.2 \\
\hline He(I) like(s) to accompany me (her) in the visits & 707 & 88.4 & 1 & 0.1 & 92 & 11.5 \\
\hline He(I) remind(s) me(her) about taking iron and vitamins & 626 & 78.6 & 7 & 0.9 & 164 & 20.5 \\
\hline Her(my) family encourage me(him) to help her(me) during pregnancy & 578 & 72.2 & 14 & 1.8 & 208 & 26.0 \\
\hline $\begin{array}{l}\text { Consent for women's discharge from hospital should be conditional on the } \\
\text { father having received perinatal health care education }\end{array}$ & 551 & 68.9 & 21 & 2.6 & 228 & 28.5 \\
\hline Community leaders can promote male participation & 524 & 65.5 & 81 & 10.1 & 195 & 24.4 \\
\hline He(I) smoke(s) beside me(her) during pregnancy & 484 & 60.5 & 7 & 0.9 & 386 & 39.0 \\
\hline He(I) do(es) not know how to help & 433 & 54.1 & 7 & 0.9 & 360 & 45.0 \\
\hline Women raised children without help in past & 408 & 51.0 & 2 & 0.4 & 389 & 48.6 \\
\hline Wives have no job except household and self care & 346 & 43.2 & 8 & 1.0 & 446 & 55.8 \\
\hline Husbands who help are called "wife's servant" & 338 & 42.2 & 9 & 1.1 & 453 & 56.6 \\
\hline He(I) help(s) when his(my) family is not present & 336 & 42.0 & 14 & 1.8 & 450 & 56.2 \\
\hline His(my) friends encourage him(me) to help me(my wife) & 214 & 26.8 & 42 & 5.2 & 544 & 68.0 \\
\hline $\mathrm{He}(\mathrm{I})$ is(am) always too tired to help me (my wife) & 208 & 26.0 & 7 & 0.9 & 583 & 73.1 \\
\hline He(I) work(s) so long and has(ve) no opportunity to help me(her) & 208 & 26.0 & 1 & 0.1 & 591 & 73.9 \\
\hline Neonatal care is not men's job & 134 & 16.8 & 13 & 1.6 & 653 & 81.6 \\
\hline $\begin{array}{l}\mathrm{He}(\mathrm{I}) \text { is(am) too busy and so has(ve) no mood to support me(her) } \\
\text { emotionally }\end{array}$ & 116 & 14.5 & 5 & 0.6 & 679 & 84.9 \\
\hline Help to a pregnant mother is not usual in his(my) family & 96 & 12.0 & 3 & 0.4 & 701 & 87.6 \\
\hline Help to a pregnant mother is not usual in our community & 86 & 10.8 & 3 & 0.4 & 711 & 88.9 \\
\hline $\mathrm{He}(\mathrm{I}) \mathrm{do}(\mathrm{es})$ not help in the perinatal period because it is a woman's job & 56 & 7.0 & 7 & 0.9 & 737 & 92.1 \\
\hline
\end{tabular}

8.2), compared with women, with a score of $57.87(\mathrm{SD} 11.48)(P<0.01)$. As shown in Table 2, the statements "Education about perinatal care is necessary for both mothers and fathers" and "Pregnant mothers need a lot of emotional support during pregnancy" had the highest rates of agreement. High rates of disagreement were recorded for the statements "Men's involvement is not necessary because pregnancy and childbirth is the mother's job", "Men's participation is not common in our society" and "Men's participation is not usual in our family".

The participants were also asked about the desired educational content; their responses are summarized in Table 3. The highest rates of agreement were for the content of "Signs of risks during pregnancy", "Postpartum complications" and "Mother's nutrition". The highest rates of disagreement were for "Baby bathing" and "Baby nappy changing".
Table 4 shows the attitude of participants about the features of education sessions. The most frequent suggestion for place was at home, for time was weekend and evening, for educator was female or midwives, for method was couples' face-to-face and using self-learning booklets. The best time to initiate the education programme was thought to be premarital classes.

The suggested education duration was 4.96 (SD 6.96; range 1-45) h for 


\begin{tabular}{|c|c|c|c|c|}
\hline \multirow[t]{2}{*}{ Educational content } & \multicolumn{2}{|c|}{ Agree } & \multicolumn{2}{|c|}{ Disagree } \\
\hline & No. & $\%$ & No. & $\%$ \\
\hline Signs of pregnancy & 704 & 88.0 & 96 & 12.0 \\
\hline Postpartum complications & 694 & 86.6 & 106 & 13.2 \\
\hline Maternal nutrition & 667 & 83.4 & 133 & 16.4 \\
\hline Pain relief for child birth & 653 & 81.6 & 147 & 18.4 \\
\hline Prenatal health & 630 & 78.8 & 170 & 21.2 \\
\hline Type of delivery (normal or caesarean section) & 630 & 78.8 & 170 & 21.2 \\
\hline Common complications of pregnancy & 629 & 78.6 & 171 & 21.4 \\
\hline Exercise during pregnancy & 628 & 78.2 & 172 & 21.5 \\
\hline Emotional changes during pregnancy & 624 & 78.0 & 176 & 22.0 \\
\hline Emotional support of mother & 620 & 77.5 & 180 & 22.5 \\
\hline Neonatal care & 611 & 76.4 & 189 & 23.6 \\
\hline Physiological changes during pregnancy & 602 & 75.2 & 198 & 24.8 \\
\hline Emotional changes for paternal adaptation & 565 & 70.6 & 235 & 29.4 \\
\hline Neonatal feeding and complementary food & 502 & 62.7 & 298 & 37.2 \\
\hline Baby bathing & 446 & 55.8 & 354 & 44.2 \\
\hline Baby napping & 390 & 48.8 & 410 & 51.2 \\
\hline
\end{tabular}

prenatal sessions and 4.95 (SD 7.19; range $1-50) \mathrm{h}$ for the postnatal period. The great majority (95.0\%) of participants believed men like to participate and $94.8 \%$ stated that men were practically involved in perinatal issues; $65.0 \%$ also stated that expectant fathers need care for emotional adaptation to fatherhood.

There were no significant differences between attitude scores of participants according age group (ANOVA $F=$ 1.32; $P=0.26$ ) but there was a statistically significant difference by education level (ANOVA $F=2.58 ; P=0.036$ ). The Tukey test showed that the illiterate group had a significantly lower score compared to the groups with primary, middle and secondary school education as well as university-educated participants $(P<0.05)$.

\section{Discussion}

This is the first study to assess educational needs of men's participation in perinatal care in the Islamic Republic of Iran. Male participation to improve maternal health is highly emphasized in the declaration of the International Conference on Population and Development in Cairo in 1994 and is considered a strategy to achieve the Millennium Development Goals [18,19].

The results showed the positive attitude of participants towards men's participation in perinatal care and that the majority believed that education is necessary for both mothers and fathers and they thought men did not know how to help; this means there is a demand for men's education. It has frequently been documented that men's education has positive effects on maternal and neonatal health [7-14].

The majority of participants stated that pregnant mothers need a lot of emotional support. In fact, the perinatal period is a time for parental adaptation to the role of parent and is an opportunity for health personnel to make the couple prepared for parenthood. Pregnant mothers experience different emotional physiologic changes which needs as much care as the physical changes do $[5,6]$. The rate of depression among pregnant mother is reported to be high and it seems that giving necessary education about emotional support has resulted in a decrease in related complications [23]. It should be noted that not only pregnant mothers, but also expectant fathers experience psychological problems [24]. Therefore, men's education seems to be necessary for their own adaptation to fatherhood. There are educational classes for parents in many countries: in Scandinavian countries $95 \%$ of fathers participate in such classes [25].

The high rate of agreement with the statement of "He (I) help(s) because the child belongs to both" and high rate of disagreement with the 3 statements "He(I) do(es) not help in perinatal because it is women's work", "Help to a pregnant mother is not usual in his(my) family" and "Help to a pregnant mother is not usual in our community" suggests that helping a pregnant mother is becoming not only a subjective norm but also a family and social norm.

The special attention to family arises from Iranian and Islamic beliefs and culture [26]. Besides, it is emphasized that "Programmes and education to 


\begin{tabular}{|c|c|c|c|c|c|c|}
\hline \multirow[t]{2}{*}{ Preferred educational arrangement } & \multicolumn{2}{|c|}{$\begin{array}{l}\text { Females } \\
(n=400)\end{array}$} & \multicolumn{2}{|c|}{$\begin{array}{c}\text { Males } \\
(n=400)\end{array}$} & \multicolumn{2}{|c|}{$\begin{array}{c}\text { Total } \\
(\boldsymbol{n}=\mathbf{8 0 0})\end{array}$} \\
\hline & No. & $\%$ & No. & $\%$ & No. & $\%$ \\
\hline \multicolumn{7}{|l|}{ Place } \\
\hline At home & 203 & 25.4 & 233 & 29.1 & 436 & 54.5 \\
\hline Health centre & 67 & 8.4 & 84 & 10.5 & 151 & 18.9 \\
\hline Workplace & 60 & 7.5 & 34 & 4.2 & 94 & 11.8 \\
\hline Physician's office & 44 & 5.5 & 28 & 3.5 & 72 & 9.0 \\
\hline Hospital & 26 & 3.2 & 21 & 2.6 & 47 & 5.9 \\
\hline \multicolumn{7}{|l|}{ Time } \\
\hline Weekend & 247 & 20.9 & 186 & 23.2 & 433 & 54.1 \\
\hline Weekday & 153 & 19.1 & 219 & 26.8 & 367 & 45.9 \\
\hline Morning & 86 & 10.8 & 26 & 3.2 & 112 & 14.0 \\
\hline Evening & 171 & 21.3 & 240 & 30.0 & 411 & 51.4 \\
\hline Night & 143 & 17.9 & 134 & 16.8 & 277 & 34.6 \\
\hline Prenatal & 77 & 9.6 & 46 & 6.8 & 123 & 15.4 \\
\hline Postnatal & 46 & 5.8 & 14 & 1.8 & 60 & 7.5 \\
\hline Prenatal \& postnatal & 277 & 34.6 & 340 & 42.5 & 617 & 77.1 \\
\hline \multicolumn{7}{|l|}{ Educator } \\
\hline Midwife/nurse & 359 & 44.9 & 390 & 48.8 & 749 & 93.6 \\
\hline Physician & 41 & 5.1 & 10 & 1.2 & 51 & 6.4 \\
\hline Female & 328 & 41.8 & 286 & 35.8 & 614 & 76.8 \\
\hline Male & 72 & 9.0 & 114 & 14.2 & 186 & 23.3 \\
\hline \multicolumn{7}{|l|}{ Method } \\
\hline Couple face-to-face & 134 & 16.8 & 172 & 21.15 & 306 & 38.3 \\
\hline Fathers group & 119 & 14.9 & 100 & 12.5 & 219 & 27.4 \\
\hline Father face-to-face & 87 & 10.9 & 64 & 8.0 & 151 & 18.9 \\
\hline By telephone & 2 & 0.2 & 0 & 0.0 & 2 & 0.3 \\
\hline Online & 2 & 0.2 & 2 & 0.2 & 4 & 0.5 \\
\hline Self-learning booklet & 14 & 1.8 & 142 & 17.8 & 156 & 19.5 \\
\hline $\mathrm{CD}$ & 129 & 16.1 & 2 & 0.2 & 131 & 16.4 \\
\hline \multicolumn{7}{|l|}{ Initiation time } \\
\hline Premarital classes & 168 & 21.0 & 164 & 20.5 & 332 & 41.5 \\
\hline Prenatal classes & 127 & 15.9 & 104 & 13.0 & 231 & 28.9 \\
\hline High school: girls and boys & 99 & 12.4 & 132 & 16.5 & 231 & 28.9 \\
\hline High school: boys & 6 & 0.89 & 0 & 0.0 & 6 & 0.8 \\
\hline
\end{tabular}

engage men's support for maternal health and safe motherhood should be developed; all countries are urged to seek changes in high-risk sexual behaviour and to devise strategies to ensure that men share responsibility for sexual and reproductive health" [18]. According to this global attempt to promote men's participation, it is essential to improve their knowledge and practice by providing the required education about maternal health. However, there is still some misconception such the humour of "wife's servant" for a husband who helps his wife, which may sometimes be a barrier. However, the role of a man is formed in the family and enhanced by community leaders and the media [27].

A high rate of agreement with the statements "Broadcasting can promote male participation in maternal health", "Movies and television serials may contribute in promotion of men's participation" and "Community leaders can promote male participation" suggests that the media can be an effective way to promote male participation, perhaps even more effective than community leaders. Thus mass media can help to overcome the barriers and promote the 
culture of gender equity and responsible sexual and reproductive behaviour. As a result, young boys should learn responsible reproductive behaviour in their families, and young girls should have enough skills to have income for financial support of themselves and their future children and finally men should involve in all responsibilities of the family, including perinatal care $[19,27]$.

The results demonstrated that the majority of men are involved in providing their wives nutrition and they care about the risks of pregnancy as well as accompanying them in the visits. This was consistent with our findings about preferred educational content, viz signs of risks and mothers' nutrition. So it can be postulated that men like to learn about the subjects that they are involved in.

Usually men are the source of finances in the Iranian family. Education about signs of risks and nutrition is necessary to make proper and timely decisions, which certainly lead to a decrease in maternal and neonatal morbidity and mortality.

Our results suggest men prefer couples' face-to-face education, which is also recommended by experts $[5,6]$. The husband's understanding and involvement are necessary, however, the inability of the husband to accompany the wife during perinatal care and counselling may arise from the system of the service provider: some do not let husbands attend as shown in this study and a study in Saudi Arabia [28]. So it is time to reorient the perinatal services based on the demand of the clients and provide a system with a defined place for counselling both mother and father together. Nowadays, prenatal services are called family-friendly services [25].

The results also indicate that men have a preference for self-learning booklets and are interested in being educated at home during the evening or at the weekend. This may be due to weekdays being busy. Educational materials (e.g. pamphlets, brochures and booklets) have been suggested to improve reproductive health services in other studies in the Islamic Republic of Iran [29]. A study in Scandinavia also showed men liked to be educated using online services. So it can be recommended that couples or men be educated about 4-6 hours in prenatal and postnatal visits separately and complementary information can be packaged in the form of booklets, CDs or other educational aids and to be sent home for self-study. There is no doubt that the services should be evaluated periodically regarding their cost effectiveness, efficacy and efficiency.

The majority of participants agreed with the statement "Fathers should have perinatal leave for the participation" and believed that they would use it. However, other research has shown men do not use it even if they have the right because it may increase their vulnerability in the workplace [27].

Most participants believed that education about male participation should be started from high school and it suggested that knowledge and attitude of both sexes towards male participation in reproductivehealthshouldbeaddressed before marriage [27]. Participation in maternal health education could be initiated from premarital classes: there are strategic programmes for parenthood education and men's involvement in reproductive health in many countries [30]. Male education about parenthood responsibilities could be considered in premarital classes, and details about male involvement in maternal health could be provided in perinatal classes. Although a majority of subjects claimed that men participate in perinatal care, the extent of their activities and average time that they spend are not clear.

There was no association between age of participants and attitude score, however illiterate participants had a statistically significantly lower attitude score compared to other groups and this finding was consistent with other studies [15].

The only significant limitation of this study was that male participants were accompanying husbands of the clients. Although some husbands had to attend hospital for women's discharge, some attended of their own will. Therefore population-based studies are suggested in similar future studies. The future studies should also consider educational interventions to find the most effective educational strategies to improve men's participation in reproductive health programmes.

\section{Acknowledgement}

We are grateful to the research secretary of Shahid Beheshti University of Medical Sciences for funding this study.

\section{References}

1. World Health Organization. Strategy to accelerate progress towards the attainment of international development goals and targets related to reproductive health. Reproductive Health Matters, 2005, 13(25):11-18.

2. Programming for male involvement in reproductive health. Report of the meeting of WHO Regional Advisers in Reproductive Health WHO/PAHO, Washington DC, USA5-7 September 2001. World Health Organization, Geneva, 2002.
3. Drennan M, Robey B. Reproductive health, new perspectives on men's participation. Baltimore, Johns Hopkins School of Public Health, 1998 (Population Reports, XXVI, Series J, No. 2 ).

4. Population Council. Maternal and child health, mixed success involving men in maternal care worldwide. Population Briefs, 2005, 11(1).

5. Lowdermilk DL, Perry SE. Maternity and women health care, 8th ed. St. Louis, Mosby, 2004. 
6. McKinney ES et al. Maternal child nursing. Philadelphia, WB Saunders Company, 2000.

7. Shefner-Rogers CL, Sood S. Involving husbands in safe motherhood: effects of the SUAMI SIAGA campaign in Indonesia. Journal of Health Communication, 2004, 9(3):233-258.

8. Turan JM et al. Including expectant fathers in antenatal education programmes in Istanbul, Turkey. Reproductive Health Matters, 2001, 9(18):114-25.

9. Turan JM, Say L. Community-based antenatal education in Istanbul, Turkey: effects on health behaviours. Health Policy \& Planning, 2003, 18(4):391-398.

10. Bhalerao VR et al. Contribution of the education of the prospective fathers to the success of maternal health care programme. Journal of Postgraduate Medicine, 1984, 30(1):10-2.

11. Carter MW, Speizer I. Salvadoran fathers' attendance at prenatal care, delivery, and postpartum care. Revista Panamericana de Salud Pública, 2005, 18(3):149-156.

12. Soliman MH. Impact of antenatal counselling on couples knowledge and practice of contraception in Mansoura, Egypt. Eastern Mediterranean Health Journal, 1999, 5 (5):1002-1013.

13. Wolfberg AJ et al. Dads as breastfeeding advocates: results from a randomized controlled trial of an educational intervention. American Journal of Obstetrics \& Gynecology, 2004, 191(3):708-712.

14. Diemer GA. Expectant fathers: influence of perinatal education on stress, coping, and spousal relations. Research in Nursing \& Health, 1997, 20(4):281-293.

15. Ozgoli G et al. [Male participation in family planning programs]. Journal of Zanzan Medical Science University, 1381, 10(40):41-45 [in Farsi].

16. Tavoosi NM, Heidarnia A. [Effects of health education on male participation in family planning]. Daneshvar, 2000, 8(30):5964 [in Farsi].

17. Movahed M, Tourajianfar H. [Association of sociocultural factors with men's attitude towards participation in family planning programs in Shiraz]. Tehran, Demography Association of Iran, 2007:92-110 [in Farsi].

18. Report of the International Conference on Population and Development, Cairo, 5-13 September 1994. New York, United Nations, 1995 (http://www.unfpa.org/webdav/site/global/shared/ documents/publications/2004/icpd_eng.pdf, accessed 13 July 2011).
19. UNFPA, Interactive Population Center. Recognizing and promoting women's key economic roles. A new role for men.(http:// web.unfpa.org/intercenter/role4men/recognize.htm, accessed 13 July 2011).

20. Crossette B. Reproductive health and millennium development. International Planned Parenthood Federation, 2011 (http:// www.ippf.org/en/What-we-do/Advocacy/Reproductive+ Health+and+the+Millennium+Development+Goals.htm, accessed 11 July 2011).

21. Simbar M et al. Fathers' educational needs for perinatal care in urban Iran: a qualitative approach. Journal of Biosocial Science, 2010, 42(5): 633-641.

22. Dawson B, Robert G. Basic and clinical biostatistics, 4th ed. New York, McGraw-Hill Company, 2004.

23. Hoseini $\mathrm{F}$ et al. [Depression during pregnancy: needs to be screened]. Journal of Gorgan Medical Science University, 1384, 7(1):60-65 [in Farsi].

24. Ghafari F, Poorghaznein T, Masloom S. [Emotional health of pregnants and their husbands during pre and postnatal period in Ramsar]. Iran Journal of Obstetrics and Gynaecology, 1384, 8(2):72-80 [In Farsi].

25. Fatherhood and health outcomes in Europe. Geneva, World Health Organization, 2007.

26. [Male participation in women empowerment]. Tehran, Women and Family Centrer of President, 2008. (http://www. women.gov.ir/pages/content.php?id=3044, accessed $3 \mathrm{Au}-$ gust 2011) [in Farsi].

27. Enhancing men's roles and responsibilities in family life. A new role for men. New York, UNFPA Interactive Population Centre, 2009. (http://web.unfpa.org/intercenter/role4men/enhancin.htm, accessed 7 June 2011).

28. Baldo $\mathrm{MH}$ et al. Integrating maternal and child health with primary health care in Saudi Arabia. Eastern Mediterranean Health Journal, 2000, 6(4):701-711.

29. Nanbakhsh $\mathrm{H}$ et al. Assessment of women's satisfaction with reproductive health services in Urmia University of Medical Sciences. EasternMediterranean HealthJournal, 2008,14(3):605614.

30. Sonenstein FL. Young men's sexual and reproductive health: toward a national strategy, getting started. Washington DC, The Urban Institute, 2000 (http://www.urban.org/ UploadedPDF/410027.pdf, accessed 7 June 2011). 